\section{A Simple Transformation System Using Adventitious Shoot Multiplication of Juneberry}

Ravindra K. Hajela, Neerja Hajela, Mark G. Bolyard',

Wayne M. Barnes ${ }^{2}$, and Mariam B. Sticklen

Departments of Crop and Soil Sciences and Entomology, 202 Pesticide Research Center, Michigan State University, East Lansing, MI 48824-1311

Additional index words. Amelanchier laevis, biotechnology, tissue culture, micropropagation, gene transfer

Abstract. A simple gene transfer method based on Agrobacterium -mediated transformation of adventitious multiplication of Juneberry (Amelanchier laevis L.) basal shoots is described. Evidence is presented for successful integration and expression of a transformed gene in greenhouse-grown transgenic plants. This method can transform woody perennials that are difficult to regenerate from leaf disks, protoplasts, or other tissue culture regimens.

Transformation of tree species was reported several years ago (Fillatti et al., 1987). Since then, introducing foreign genes into tree species has become more feasible for those trees that can be regenerated efficiently in vitro from leaf disks, protoplasts, or cell lines (Haissig, 1989). The purpose of this report is to describe a transformation system for Juneberry, which undergoes in vitro adventitious shoot multiplication from the bases of individual shoot explants that easily root in soil and develop into normal plants (Behrouz, 198 1). We have used Juneberry as a model for other woody plant species that can proliferate adventitious shoots efficiently in vitro because of the plant's intrinsic value as a forest and ornamental species.

Juneberry shoot-tip explants $(\approx 2 \mathrm{~cm}$ long) were harvested originally from a greenhousegrown plant; surface-sterilized in $5.25 \%$ $\mathrm{NaOC} 1$; rinsed three times with autoclaved distilled, water; and cultured in Magenta GA7 vessels (Magenta Corp., Chicago) containing a shoot multiplication medium (Behrouz, 198 1). The multiplication medium consisted of Murashige and Skoog (MS) (1962) basal medium supplemented with $3 \%$ sucrose, myoinositol at $100 \mathrm{mg} \cdot \mathrm{liter}^{-1}$, casein enzymatic hydrolysate. at $200 \mathrm{mg} \cdot \mathrm{liter}^{-1}$, thiamine at 100 $\mathrm{mg} \cdot$ liter $^{-1}$, and $2.5 \mu \mathrm{m}$ benzyladenine. This

Received for publication 19 Oct. 1992. Accepted for publication 17 Jan. 1993. This work was supported by grant CA 3040-9-8003 from the U.S. National Park Service to M.B.S. The cost of publishing this paper was defrayed in part by the payment of page charges. Under postal regulations, this paper therefore must be hereby marked advertisement solely to indicate this fact.

${ }^{1}$ Present address: Dept. of Biological Sciences, Southern Illinois Univ. at Edwardsville, Edwardsville, IL 62026-1651.

${ }^{2}$ Dept. of Biochemistry and Molecular Biophysics, Washington Univ. School of Medicine, St. Louis, MO 63110.

${ }^{3}$ To whom reprint requests should be addressed. medium is hereafter referred to as modified MS medium (MMSM).

About 100 adventitious shoots were regenerated from the basal cut portion of each single shoot cultured in MMSM within 6 to 10 weeks (Fig. 1). These in vitro-grown shoots were used further for the transformation studies described below.

A kill curve experiment was conducted to identify the level of kanamycin sulfate (KS) required for selecting putatively transgenic shoots in vitro. In this experiment, Juneberry shoot explants ( $2 \mathrm{~cm}$ long) were obtained from in vitro-cultured material. Explants were cul- tured on MMSM supplemented with $\mathrm{KS}$ at 0 , 4 , 16, or $64 \mathrm{mg} \cdot$ liter $^{-1}$. Five jars, each containing 10 shoot explants, were used for each concentration. While KS at $4 \mathrm{mg} \cdot$ liter $^{-1}$ did not affect growth or shoot multiplication rate, those cultured in $\mathrm{KS}$ at $16 \mathrm{mg} \cdot \mathrm{liter}^{-1}$ reduced adventitious shoot production five-fold relative to controls. All of the shoots cultured in medium containing KS at $64 \mathrm{mg} \cdot$ liter $^{-1}$ showed evidence of bleaching and died within 2 weeks.

The plasmids pWB139 (Cheng et al., 1992) and pWB195 (Fig. 2) were constructed. These plasmids contain an in-frame translational fusion between the amino terminal 612 amino acids of a Bacillus thuringiensis var. kurstaki gene encoding the toxin I-ID73 fused to the neomycin phosphotransferase II (npt II) gene (rendering resistance to the aminoglycoside antibiotics KS and neomycin) from the Escherichia coli transposon Tn5. These plasmids are based on a modification of the plasmid pWB146 (Barnes, 1990). This plasmid's gene cassette is regulated by the cauliflower mosaic virus $35 \mathrm{~S}(35 \mathrm{~S})$ promoter and tomato proteinase inhibitor I terminator (Tom pi I). Plasmid pWB139 also contains a nopaline synthase (nos) promoter upstream of the $35 \mathrm{~S}$ promoter and a nos terminator downstream from the Tom pi I terminator. Plasmid pWB139 has only the right border at the 5' end, and pWB195 has a left border at the 5' end and a right border and over drive at the 3' end of the gene cassette. Unless specified, all reagents used for these experiments were from Sigma Chemical, St. Louis.

The disarmed Agrobacterium tumefaciens strain WAg11 (Barnes, 1990) containing plasmids pWB139 and pWB195 was used to transform Juneberry. To transform this species, the

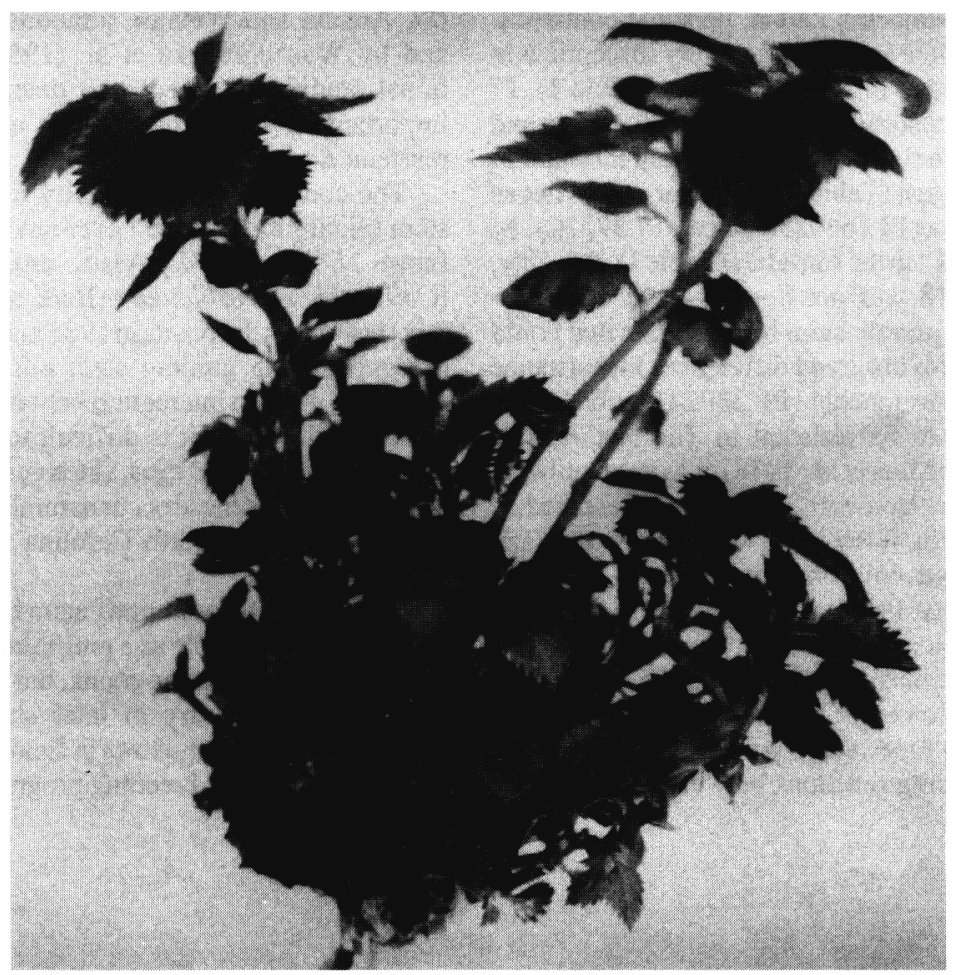

Fig. 1. Regenerating adventitious shoots from a single control shoot cultured for 4 weeks on modified Murashige and Skoog (1962) medium supplemented with $2.5 \mu \mathrm{m}$ benzyladenine. 
pWB 139

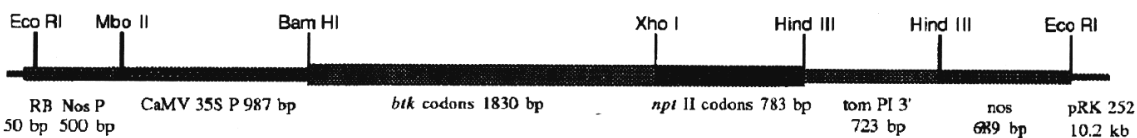

pWB 195

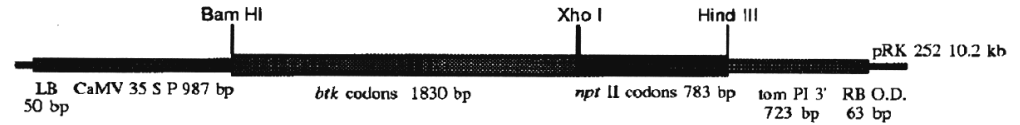

Fig. 2. Restriction maps of pWB195 and pWB139. Scale: 300 nucleotides/cm (except the vector pRK 252).

shoot multiplication area $(0.5$-cm-long basal cut ends) of shoot explants was co-cultivated overnight at $24 \pm 2 \mathrm{C}$ in sterile, borosilicate, 12- $\times 75$-mm culture tubes (VWR Scientific, South Plainfield, N.J.) containing a 1: 1 dilution of an overnight culture of $A$. tumefaciens carrying pWB139 or pWB195 and MMSM supplemented with $\mathrm{KS}$ at $20 \mathrm{mg} \cdot \mathrm{liter}^{-1}$ and tetracycline at $10 \mathrm{mg} \cdot$ liter $^{-1}$.

After co-cultivation, explants were rinsed twice in MS medium containing Augmentin 250 (Beecham, Bristol, Tenn.) at $250 \mathrm{mg} \cdot \mathrm{liter}^{-1}$, then cultured on solidified phytoagar (Gibco/ BRL Life Technologies, Gaithersburg, Md.) at $6.5 \mathrm{mg} \cdot$ liter $^{-1}$, MMSM containing Augmentin at $250 \mathrm{mg} \cdot$ liter $^{-1}$, and $\mathrm{KS}$ at $16 \mathrm{mg} \cdot \mathrm{liter}^{-1}$. The effective activity of KS may have been reduced somewhat by the presence of Augmentin during the selection culture period. Cultures were maintained for 3 to 4 months at $24 \pm 2 \mathrm{C}$ under a 16-h photoperiod of $40 \mu \mathrm{mol} \cdot \mathrm{m}^{-2} \cdot \mathrm{s}^{-1}$. The regenerated shoots were transferred monthly onto fresh medium containing Augmentin and KS. After 3 to 4 months, KSresistant and control (nontransformed) shoots were transferred for rooting to 7.5 -cm-diameter (250-ml) clay pots containing a medium of 1 peat : 1 perlite $(\mathrm{v} / \mathrm{v})$. The pots containing shoots were enclosed in plastic bags for 2 to 3 weeks to maintain high humidity. Small holes (2 to $3 \mathrm{~mm}$ in diameter) were made in the bags every 2 to 3 days to acclimate the plantlets to the lower relative humidity in the greenhouse. Plantlets also were acclimated to greenhouse conditions by increasing irradiance during 3 to 4 weeks of rooting. Rooted shoots (plantlets) were transferred to the greenhouse. All plantlets rooted when 2- to 3-cm-long shoots with more than four well-expanded leaves were used.

DNA was extracted from young leaves of putatively transformed and control plants following the method of Rogers and Bendich (1985). Barn HI (a site at the start codon of the Bt gene)-digested genomic DNA was electrophoresed on $1 \%$ agarose gels, then transferred to a Nytran nylon membrane (Schleicher and Schuell, Keene, N.H.) following procedures of Southern (1975). A 2.6-kb Barn HI/Hind III fragment from pWB139 containing Btk/npt II codons was used as a probe. Filters containing restricted DNA were incubated with a ${ }^{32} \mathrm{P}$ - labeled probe $\left[{ }^{32} \mathrm{P}\right.$-deoxycytidine 5 '-triphosphate, $800 \mathrm{Ci} / \mathrm{m}$ per mol$(1 \mathrm{Ci}=37 \mathrm{GBq})$; New England Nuclear Research Products, Boston] prepared using random hexamers (Pharmacia LKB Biotechnology, Piscataway, N.J.) following procedures of Feinberg and Vogelstein (1983). Filters were washed using standard methods (Sambrook et al., 1989) and subjected to autoradiography using Kodak XOmat AR-5 film (Eastman Kodak, Rochester, N.Y.). The restriction enzymes and the Klenow fragment of DNA polymerase I were from New England Biolabs, Beverly, Mass.

In a typical experiment, up to 100 adventitious shoots were regenerated from control (nontransformed) and co-cultivated explants within 6 to 8 weeks. When putatively transformed shoot explants were selected in $\mathrm{KS}$ at $16 \mathrm{mg} \cdot$ liter $^{-1}$ containing MMSM, 15 to 20 adventitious shoots were regenerated from each cultured shoot. Of 38 randomly selected Juneberry adventitious shoots regenerated after co-cultivation with Agrobacterium carrying pWB139, pWB195, or both and selected in $\mathrm{KS}$ at $16 \mathrm{mg} \cdot \mathrm{liter}^{-1}$ containing MMSM, nine showed positive hybridization signals on southem blots (Fig. 3). DNA was digested with Bam HI. Any integrated DNA cut with Bam HI will cut at this site and in the plant genome 3' to the point of integration. Any piece that hybridizes with a Btk/npt II probe should be $>4 \mathrm{~kb}$ for pWB139 and >3.3 kb for pWB195. Since pWB139 has no left-border t-DNA sequences,

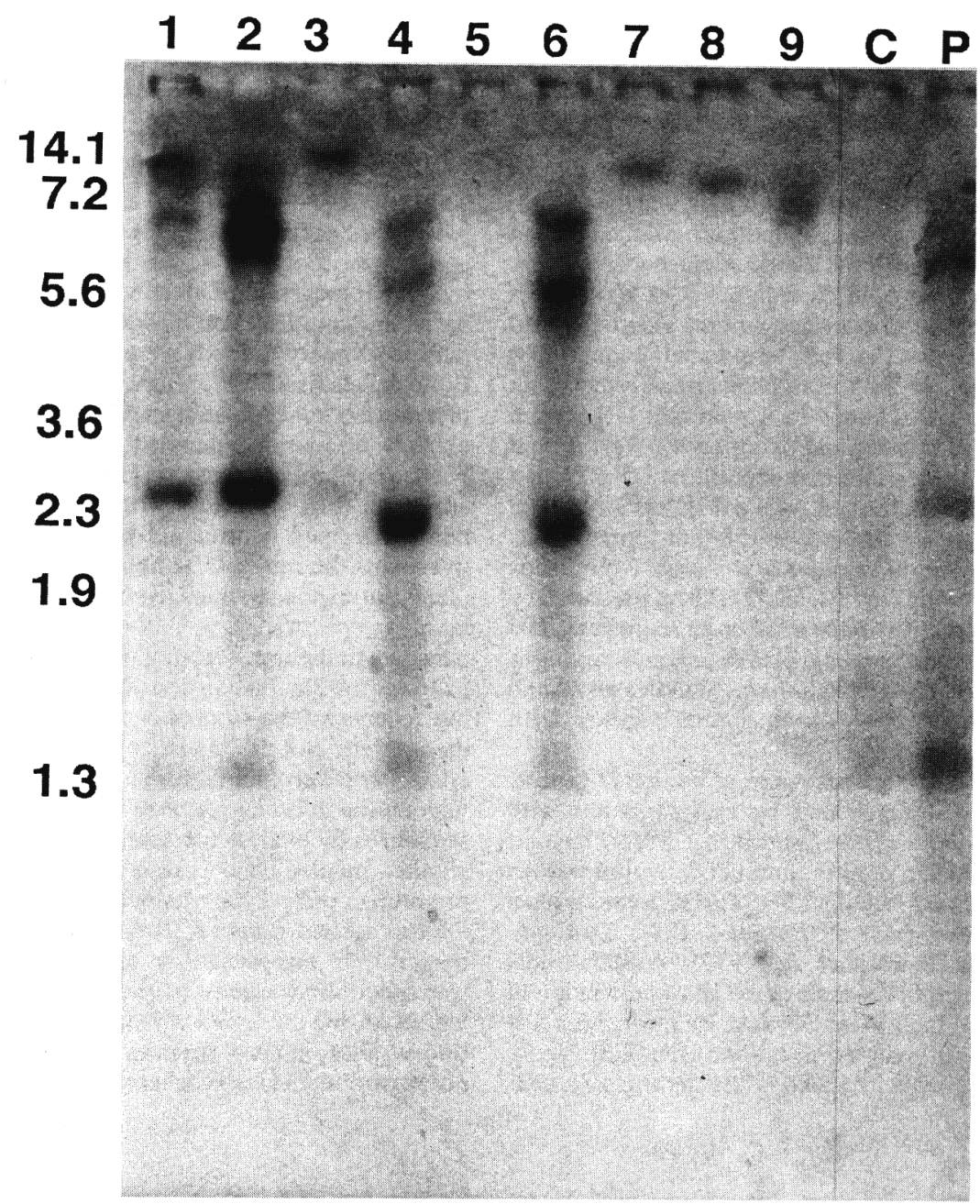

Fig. 3. Autoradiogram of Southern blot of Bam HI-digested total DNA from Juneberry plants co-cultivated with Agrobacterium containing pWB139 (lanes 1-4), pWB139 and pWB195 (lanes 5-8), or pWB195 (lane 9). Lane C contains DNA from a nontransformed plant and lane P from the plasmid pWB195 DNA digested with Bam HI and HindIII. Molecular weights are given in kilobase pairs. 


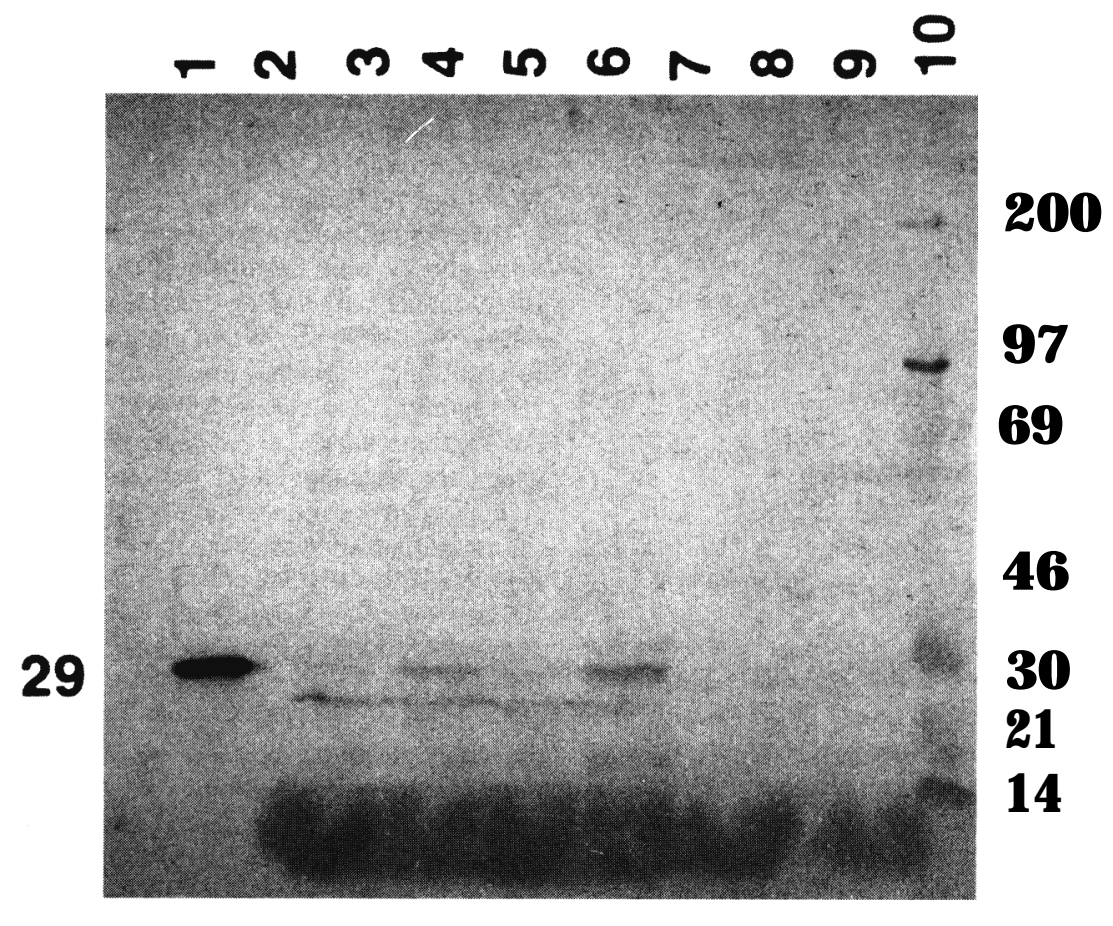

Fig. 4. Western blot of protein extracted from four independent transformants probed with anti- npt II antibody: positive control $29 \mathrm{kDa} n p t$ II protein (lane 1), four independently transformed plants (lanes 3-6), and a negative control plant (lane 9). Lanes 2 and 8 were left empty. Numbers on the right refer to protein marker sizes in kiloDaltons.

a characteristic that would denote the $3^{\prime}$ integration site, predicting the size of the inserted DNA is difficult. Bands represent fragments extending from the internal Bam HI site to a distal site in the plant genome where plasmid integration has been terminated. Lanes 1 to 4 represent DNA from plants transformed with pWB139, lanes 5 to 8 represent DNA from plants transformed using both pWB139 and pWB195, and lane 9 represents DNA from a plant transformed with pWB195 only. Most lanes representing pWB195-transformed plants have only high-molecular-weight DNA bands of varying lengths, all $>3.3 \mathrm{~kb}$, as predicted by the presence of the left-border sequences. The size heterogeneity of DNA bands giving a positive hybridization signal indicates that no shoots were contaminated further with Agrobacterium.

To detect expression of the npt II gene in plants transformed by co-cultivation with Agrobacterium containing pWB139 and pWB195, protein immunodetection assays were performed on SDS PAGE western blots of plant extracts (Burnette, 1981; Laemmli, 1970; Towbin et al., 1979). Western blots were probed using a rabbit anti- npt II antibody (5'-3' Inc., West Chester, Pa.), to which $1 \%$ normal goat serum (Gibco BRL Life Technologies) was added while the primary anti- body was incubated with the membrane to reduce the background. Purified npt II protein, used as positive control, was also from $5^{\prime}-3^{\prime}$ Inc. Other reagents for alkaline phosphatasebased immunodetection of bound goat, antirabbit secondary antibody were from Promega Biotech, Madison, Wis. Nitrocellulose membranes were from Schleicher and Schuell. Leaf extracts of four independently transformed plants showed a positive npt II signal on westem blots (Fig. 4, lanes 3-6), whereas the nontransformed control did not react positively with the anti- npt II antibody. These four plants correspond to transgenic plants used in lanes 5 to 8 of Fig. 3. Although the gene cassettes in the transforming plasmids are an in-frame translational fusion of Btk/nptII coding sequences, the sizes of positive bands on the western blot are similar to those for the control npt II protein, This result suggests the fusion protein is cleaved to remove the npt II sequences by plant cytoplasmic proteases. A slightly smaller band is also seen and may represent a proteolytic product.

The system reported herein was used to demonstrate the possibility of transforming tree species that cannot be regenerated from leaf disks, but that efficiently produce adventitious shoots in vitro. An insect bioassay was not performed, since Juneberry is resistant to most lepidopteran insects [e.g., tobacco hornworm (Manduca sexta L.)] used in Bt transformation studies.

Although producing adventitious shoots does not eliminate the possibility of somaclonal variation (Larkin and Scowcroft, 1981), all plants regenerated in vitro were morphologically alike. Although samples for molecular analysis were taken from different parts of each transgenic plant, more experiments are required to demonstrate if these transgenic plants are chimerically transformed.

\section{Literature Cited}

Barnes, W.M. 1990. Variable patterns of expression of luciferase in transgenic tobacco leaves. Proc. Natl. Acad. Sci. USA 87:9183-9187.

Behrouz, M.B. 1981. Micropropagation and photomorphogenesis of Amelanchier laevis in vitro. $\mathrm{PhD}$ Diss., The Ohio State Univ., Columbus.

Burnette, W.N. 1981. "Western blotting": Electrophoretic transfer ofroutines from sodium dodecyl sulfate-polyacrylamide gels to unmodified nitrocellulose and radiographic detection with antibody and radioiodinated protein A. Anal. Biochem. 112:195-203.

Cheng, J., M.G. Bolyard, R. Saxena, and M.B. Sticklen. 1991. Production of insect resistant potato by genetic transformation with a $\alpha-$ endotoxingene from Bacillus thuringiensis var. kurstaki. Plant Sci. 81:83-91.

Feinberg, A.P. and B. Vogelstein. 1983. A technique for radiolabeling DNA restriction endonuclease fragments to high specific activity. Anal. Biochem. 132:6-13.

Fillatti, J., J. Sellmer, B. McCown, B. Haissig, and L. Comai. 1987. Agrobactetium mediated transformation of Populus. Mol. Gen. Genet. 206:192-199.

Haissig, B.E. 1989. Status of forest tree vegetative regeneration for biotechnology. Amer. Biotechnol. Lab. 7:48-51.

Laemmli, U.K. 1970. Cleavage of structural proteins during the assembly of the head of bacteriophage T4. Nature 227:680-685.

Larkin, P.J. and W.R. Scowcroft. 198 1. Somaclonal variation-A novel source of variability from cell cultures for plant improvement. Theoretical Applied Genet. 60:197-214.

Murashige, T. and F. Skoog. 1962. A revised medium for rapid growth and bioassays with tobacco tissue cultures. Physiol. Plant 15:473497

Rogers, S.O. and A.J. Bendich. 1985. Extraction of DNA from milligram amounts of fresh, herbarium, and mummified plant tissues. PlantMol. Biol. 5:69-76.

Sambrook, J., E.F. Fritsch, and T. Maniatis. 1989. Molecular cloning-A laboratory manual. vol. 3.2nd ed. Cold Spring Harbor Lab. Press, Cold Spring Harbor, N.Y.

Southern, E.M. 1975. Detectionof specific sequences among DNA fragments separated by gel electrophoresis. J. Mol. Biol. 98:503-517.

Towbin, H., T. Staehelin, and J. Gordon. 1979. Electrophoretic transfer of proteins from polyacrylamide gels to nitrocellulose sheets: Procedures and some applications. Proc. Natl. Acad. Sci. USA 76:4350-4354. 